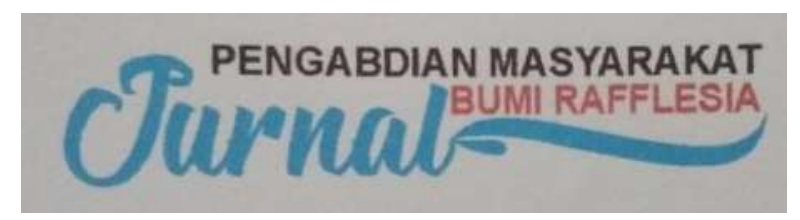

\title{
LAPORAN KEUANGAN KOPERASI BERBASIS MEDIA EXCEL FOR ACCOUNTING (EFA)
}

\author{
Yusmaniarti ${ }^{1}$ \&Sri Ekowati ${ }^{2}$
}

\author{
${ }^{1,}$ Program Studi Akuntansi \\ ${ }^{2}$ Program Studi Manajemen
}

Fakultas Ekonomi Universitas Muhammadiyah Bengkulu

Correponding author : yusmaniarti8@gmail.com

\begin{abstract}
ABSTRAK
Setiap perusahaan atau badan usaha harus memiliki laporan keuangan pada akhir periode perusahaan dapat mengetahui jumlah aktiva, kewajiban, ekuitas, pendapatan serta biaya yang dikeluarkan perusahaan selama satu periode yang bersangkutan. Perusahaan juga akan tebih mudah untuk mengambil suatu keputusan apakah perusahaannya akan diteruskan atau dijual dan menanamkan modalnya ke perusahaan lain. Koperasi Matahari juga mempunyai modal yang cukup besar dan volume transaksi yang tinggi. Koperasi Matahari telah melakukan penyusunan laporan keuangan akan tetapi masih sacara manual, belum menggunakan sistem informasi akuntansi, sehingga laporan tidak bisa disajikan secara cepat. Kegiatan pengabdian ini ini bertujuan untuk memberikan pendampingan penyusunan laporan keuangan koperasi dengan menggunakan Excel For Accounting (EFA) yang sesuai dengan prinsip akuntansi. Program ini digunakan karena tidak sulit dan sudah familiar sehingga Koperasi matahari tidak terlalu kesulitan untuk mempelajari dan menggunakannya. Selain itu, program ini juga mempunyai banyak keunggulan dan fasilitas yang dapat disesuaikan dengan kebutuhan Koperasi. Adapm laporan keuangan yang dibuat adalah neraca, laba rugi, laporan perubahan ekuitas dan laporan arus kas.Masalah utama yang menjadi fokus dalam pengembangan koperasi adalah mengenai pengelolaan keuangan. Pengelolaan keuangan pada koperasi membutuhkan keterampilan Akuntansi yang baik oleh pengelolah koperasi. Laporan keuangan merupakan alat yang sangat penting untuk memperoleh informasi mengenai posisi keuangan perusahaan dan kinerja keuangan yang dicapai oleh suatu entitas. Informasi yang digunakan untuk mengetahui kondisi dan perkembangan suatu entitas adalah laporan keuangan yang dilaporkan setiap akhir periode sebagai laporan atas pengelolaan suatu entitas.Bentuk kegiatan yang akan dilaksanakan adalah pelatihan dan workshop penyusunan laporan keuangan koperasi Matahari dengan mnggunakan aplikasi microsof excel yaitu aplikasi Excel For Accounting (EFA), workshop penyusunan rekening, pencatatan transaksi,memposting,penyusunan laporan keuangan dan workshop evaluasi dari pelaksanaan penyusunan laporan keuangan yang sudah dilaksanakan. Dari kegiatan ini target dan hasil capaiannya adalah: terlaksananya kegiatan kegiatan pengabdian secara lancar, meningkatkan pemahaman para pengurus koperasi menyusun laporan keuangan sesuai SAK ETAP.
\end{abstract}

Kata Kunci : Laporan Keuangan, SAK ETAP, EFA. 


\section{PENDAHULUAN}

Koperasi merupakan salah satu dari UKM yang sering ditemui di lingkungan masyarakat. Menurut Undang-Undang Koperasi No.25 tahun 1992, Koperasi adalah badan usaha yang beranggotakan orang-orang atau badan hukum koperasi dengan melandaskan kegiatannya berdasarkan prinsip koperasi sekaligus sebagi gerakan ekonomi rakyat yang berdasar atas asas kekeluargaan.

Kepala Dinas Koperasi Pembinaan Usaha Kecil Mikro dan Menengah Kota Bengkulu, Erwan Syafrizal SE mengatakan sampai saat ini terdata sudah 788 unit koperasi yang berkembang di Kota Bengkulu. "788 unit koperasi ada di Kota Bengkulu sampai tahun 2014. Ini merupakan angka yang cukup banyak," katanya.Menurut Erwan perkembangan koperasi di Kota Bengkulu terus berkembang bahkan perkembangannya jika dirata-ratakan mengalami pertumbuhan 10 sampai 15 persen per tahunnya. "Animo masyarakat sangat tinggi untuk pembentukan koperasi sehingga tidak heran banyak koperasi yang tumbuh dengan lancar sampai tahun 2014 ini," tambahnya.Menurut dia lancarnya pertumbuhan koperasi selain dikarenakan kepercayaan masyarakat yang sudah semakin tinggi terhadap koperasi. Karena didukung dengan realisasinya program Samisake untuk seluruh kelurahan di Kota Bengkulu. "Yang paling tinggi tumbuh yakni koperasi yang bergerak dibidang simpan pinjam lalu diikuti koperasi dibidang jasa dan sebagainya,".

Menurut Erwan dengan tingginya pertumbuhan Kelembagaan koperasi dapat memberikan penguatan perekonomian dalam rangka penanggulangan kemiskinan dan pengangguran di Kota Bengkulu. Laporan keuangan juga dapat menjadi tolak ukur bagi pemilik dalam memperhitungkan keuntungan yang diperoleh, mengetahui berapa tambahan modal yang dicapai, dan juga dapat mengetahuibagaimana keseimbangan hak dan kewajiban yang dimiliki. Setiap keputusan yang diambil oleh pemilik dalam mengembangkan usahanya akan didasarkan pada kondisi keuangan yang dilaporkan secara lengkap bukan hanya didasarkan pada laba semata

Laporan keuangan koperasi harus mempunyai, kualitas seperti dapat diandalkan, relevan, akurat, tepat waktu dapat diperbandingkan. Hal ini tidak terlepas dari pengetahuan pengurus koperasi dalam menyusun laporan keuangan koperasi. Pengurus Koperasi sedikit sekali yang berlatar belakang berpendidikan di bidang akuntansi sehingga penyusunan laporan keuangan koperasi belum menggunakan Standar Akuntansi Keuangan.Laporan keuangan yang disusun baru menggunakan format yang sederhana belum menggunakan Standar yaitu SAK ETAP. Koperasi merupakan suatu entitas yang juga harus memberikan informasi keuangan kepada pemakainya yaitu anggota koperasi yang dipertanggungjaabkan melalui Rapat Anggota Tahunan. Untuk meningkatkan kemampuan pengurus koperasi menyusun laporan keuangan maka perlu dilakukan upaya baik melalui sosialisasi, pelatihan, maupun pendampingan langsung kepada koperasi.

Penerapan akuntansi dalam laporan keuangan menjadi salah satu komponen mutlak yang harus dimiliki oleh koperasi jika mereka ingin mengembangkan usahanya. Begitu pula dengan SAK ETAP sebagai standar yang mengatur pembuatan laporan untuk koperasi. Keberadaan SAK ETAP seharusnya menjadi hal yang harus diketahui dan diterapkan dalam laporan keuangan koperasi. Setelah dilakukan penelitian awal, yang dilakukan di Dinas Koperasi Kota Bengkulu dengan cara mewawancarai petugas penyuluh koperasi (Desi Mulyati). Diketahui bahwa SAK ETAP telah disosialisasi ke koperasi, sosialisasi tersebut dilakukan dengan cara 
memberikan pelatihan dalam melaksanakan pembukuan keuangan. Sosialisasi tersebut dilakukan juga dengan cara mengirimkan para petugas penyuluh koperasi untuk membantu pengurus dalam melaksanakan laporan keuangan.

Standar yang digunakan untuk menyusun laporan keuangan usaha kecil dan menengah adalah Standar Akuntansi Keuangan Entitas Tanpa Akuntabilitas Publik (SAK ETAP) yang disahkan oleh Dewan Standar Akuntansi Keuangan pada tanggal 19 mei 2009. Kehadiran Standar Akuntansi Keuangan Entitas Tanpa Akuntabilitas Publik (SAK ETAP) diharapkan dapat memberikan kemudahan untuk UKM dan koperasi dalam menyajikan laporan keuangan. Tujuan dari SAK ETAP adalah untuk memberikan kemudahan bagi entitas skala kecil dan menengah dalam menyajikan laporan keuangan tanpa terjebak dalam kerumitan standar berbasis IFRS yang akan diadopsi dalam standar akuntansi PSAK.

Sesuai dengan ruang lingkup SAK ETAP, maka standar ini dimaksudkan untuk digunakan oleh entitas tanpa akuntabilitas publik. Entitas tanpa akuntabilitas publik yang dimaksud adalah entitas yang tidak memiliki akuntabilitas publik signfikan dan menerbitkan laporan keuangan untuk tujuan umum bagi pengguna eksternal. Contoh pengguna eksternal adalah pemilik yang tidak terlibat dalam pengelolaan bisnis, kreditor yang ada dan calon kreditor, agen pemeringkatan kredit (Bruce Mackenzie Dkk, 2012: 1-2).

Penggunaan komputer pada berbagai bidang sangat membantu pekerjaan. Hal itu pun termasuk dalam bidang ekonomi. Banyak pelaku ekonomi menggunakan komputer dengan fungsi salah satunya adalah untuk pengolahan proses akuntansi seperti membukukan transaksi keuangan dengan tujuan untuk mempermudah, mempercepat dan menghemat biaya. Pengguaan komputer untuk pengolahan proses akuntansi adalah suatu kebutuhan besar. Oleh karena itu, sangat diperlukan pengenalan penggunaan komputer di bidang akuntansi sedini mungkin kepada para pemakai akuntansi agar mereka mempunyai wawasan yang luas tentang penggunaan komputer dalam proses akuntansi dan dapat memanfaatkan komputer dalam prakter kerja akuntansi secara maksimal.

Penggunaan komputer akuntansi akan mempermudah proses penyusunan laporan keuangan. Komputer akuntansi menciptakan sistem akuntansi yang mudah dan praktis, sehingga tidak ada alasan untuk mengatakan bahwa komputer akuntansi sulit untuk diterapkan. Bagian utama yang dilakukan dalam komputerisasi akuntansi adalah menginput transaksi. Menyusun laporan keuangan menggunakan komputer dapat mempermudah sehingga memperoleh informasi keuangan di media yang praktis. Kecepatan dan akurasi merupakan sumbangan yang nyata dari komputer akuntansi.

Dengan perkembangan teknologi informasi yang sedemikian canggih, maka sekarang komputer menjadi alat yang sangat penting dalam kegiatan operasional perusahaan terutama dalam penyusunan laporan keuangan. Akan tetapi, tidak semua perusahaan telah menggunakan komputer dalam penyusunan laporan keuangannya. Padahal dengan menggunakan teknologi komputer dapat membantu serta mempermudah perusahaan dalam menyusun laporan keuangan.

Penyusunan laporan keuangan dapat dilakukan dengan beberapa program, seperti Microsoft Acces, Microsoft Excel, Accurate, MYOB Accounting, dan lainlain. Salah satu yang paling banyak digunakan saat ini adalah program Excel forAccounting (EFA). EFA merupakan salah satu program aplikasi komputer yang dapatdigunakan dalam mengolah data dan 
menyajikan laporan keuangan perusahaan. Dengan Excel for Accounting (EFA), data keuangan dapat diolah secara cepat dan akurat, sehigga menghemat waktu, aktivitas dan kegiatan operasional perusahaan.

\section{METODE KEGIATAN}

a. Pelatihan

tentang

siklus

akuntansikoperasi menggunakan

EFA

Kegiatan ini bertujuan untuk memberikan pemahaman para pengurus koperasi tentang siklus akuntansi koperasi dari tahap pencatatan sampai ke pelaporan keuangan berdasarkan SAK ETAP.

\section{b. Workshop untuk}

\section{pembuatanformulir-formulir pencatatan Auntansi}

Dalam kegiatan worksop ini bertujuan untuk memberika pemahaman kepada pengurus koperasi tentang pembuatan formulir-formulir pencatatan, yang meliputi 1). Jurnal penerimaan kas, 2). Jurnal pengeluaran kas, 3). jurnal umum,4).Buku besar. Serta menganalisis dokumen keuangan, mencatat transaksi dalam jurnal, memindahbukukan transaksi ke buku besar

\section{c. Workshop penyusunan laporan keuangan berdasarkan SAK ETAP}

Kegiatan ini bertujuan untuk menjelaskan dan memberikan pemahaman kepada pengurus koperasi tentang komponendan penyusunan laopran keuangan berdasarkan SAK ETAP yang terdiri dari :

1. Neraca

2. Perhitungan Hasil Usaha

3. Catatan Atas Laporan Keuangan.

4. Laporan Perubahan Ekuitas Laporan Arus Kas

\section{d. Workshop Evaluasi Pelaksanaan Penyusunan Laporan Keuangan}

Kegiatan ini bertujuan untuk mengevaluasi pelaksanaan penyusunan laporan keuangan yang sudah dibuat oleh pengurus koperasi mitra.
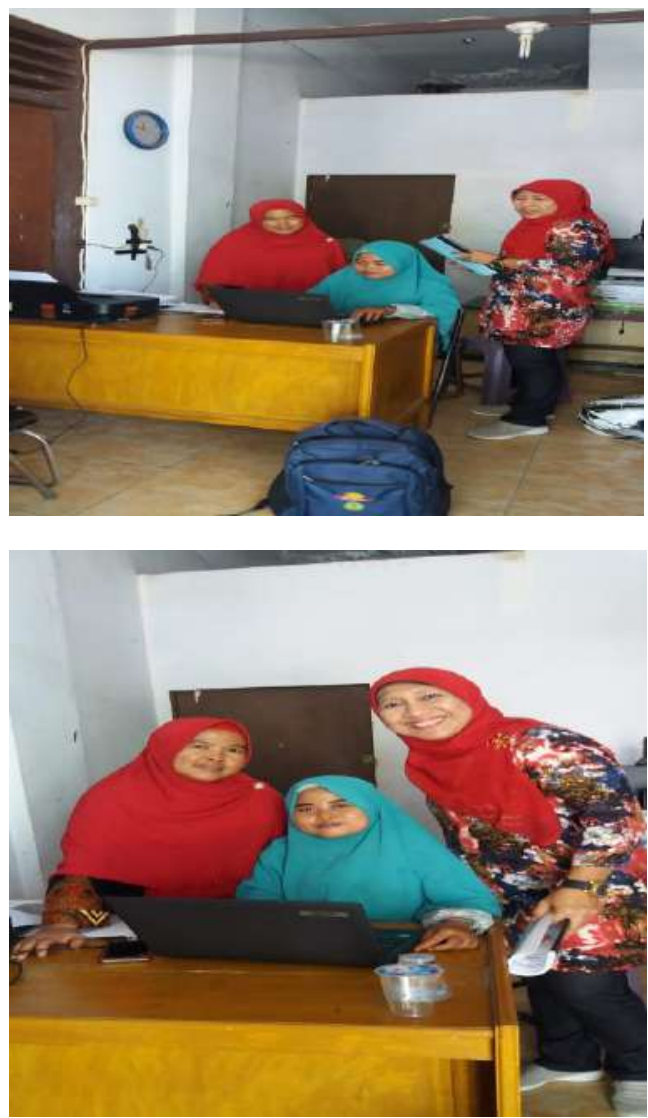

Gambar 1. Penyusuan Laporan

Keuangan berbasis EFA

Kegiatan Pengabdian ini bersifat terjadwal. Kegiatan dilaksanakan selama 3 bulan. Kegiatan dimulai dari bulan Oktober 2018 sd. Desember 2018. Kegiatan dilaksanakan secara rutin dalam persiapan penyusunan laporan keuangan berbasis Excel For Accounting.

\section{HASIL DAN PEMBAHASAN}

a. Hasil

Penyelesaian siklus Akuntansi dengan Excel 
Langkah awal pembuatan daftar rekening

Merancang Atau Membuat nomor akun Sesuai dengan kelompok masing-masing akun sesuai yang dibutuhkan, harta nomor akunnya diawalih dengan 1 , hutang diawali dengan angka 2,Modal Angka 3,pendapatan angka 3 dan beban-beban angka 5.Misal :

Harta Lancar

\begin{tabular}{|l|l|}
\hline No Akun & Keterangan \\
\hline $1-000$ & Kas \\
\hline $1-001$ & Bank \\
\hline $1-002$ & Piutang Anggota \\
\hline $1-004$ & Piutang Karyawan \\
\hline $1-005$ & Pitang Listrik \\
\hline
\end{tabular}

Harta Tetap

\begin{tabular}{|l|l|}
\hline No Akun & Keterangan \\
\hline $1-200$ & Inventaris Kantor \\
\hline $1-2001$ & $\begin{array}{l}\text { Akm.Peny } \\
\text { Inventaris }\end{array}$ \\
\hline $1-3000$ & Gedung \\
\hline $1-3001$ & $\begin{array}{l}\text { Akm.Peny } \\
\text { Gedung }\end{array}$ \\
\hline
\end{tabular}

Hutang Lancar

\begin{tabular}{|l|l|}
\hline No Akun & Keterangan \\
\hline $2-000$ & Utang usaha \\
\hline $2-001$ & Utang Dana-dana \\
\hline
\end{tabular}

Hutang Jangka Panjang

\begin{tabular}{|l|l|}
\hline No Akun & Keterangan \\
\hline $2-1000$ & Hutang BMT \\
\hline $2-10001$ & $\begin{array}{l}\text { Simpanan } \\
\text { Sukarela }\end{array}$ \\
\hline
\end{tabular}

Modal

\begin{tabular}{|l|l|}
\hline No Akun & Keterangan \\
\hline $3-000$ & Simpanan Pokok \\
\hline $3-001$ & Simpanan Wajib \\
\hline $3-100$ & SHU Anggota \\
\hline $3-200$ & $\begin{array}{l}\text { SHU Tahun } \\
\text { Berjalan }\end{array}$ \\
\hline
\end{tabular}

Pendapatan

\begin{tabular}{|l|l|}
\hline No Akun & Keterangan \\
\hline
\end{tabular}

\begin{tabular}{|l|l|}
\hline $4-000$ & $\begin{array}{l}\text { Pendapatan } \\
\text { Bunga }\end{array}$ \\
\hline $4-001$ & $\begin{array}{l}\text { Pendapatan } \\
\text { ADM }\end{array}$ \\
\hline $4-002$ & $\begin{array}{l}\text { Pendapatan } \\
\text { Lain-lain }\end{array}$ \\
\hline
\end{tabular}

Beban-Beban

\begin{tabular}{|l|l|}
\hline No Akun & Keterangan \\
\hline $5-000$ & Biaya Adm \\
\hline $5-001$ & Biaya Gaji \\
\hline $5-002$ & Biaya THR \\
\hline
\end{tabular}

Setelah Merancang/membuat nomor akun sesuai dengan kempok akun,setelah itu baru kita membuat daftar rekening sesuai dengan no akun yang telah kita buat.

\section{a. Daftar Rekening}

Siklus Akuntansi dimulai dengan membuat lembar kerja (Work Sheet),Daftar rekening langkahnya adalah sebagai berikut :

Ketik daftar rekening seperti contoh Koprasi Matahari seperti dibawah ini

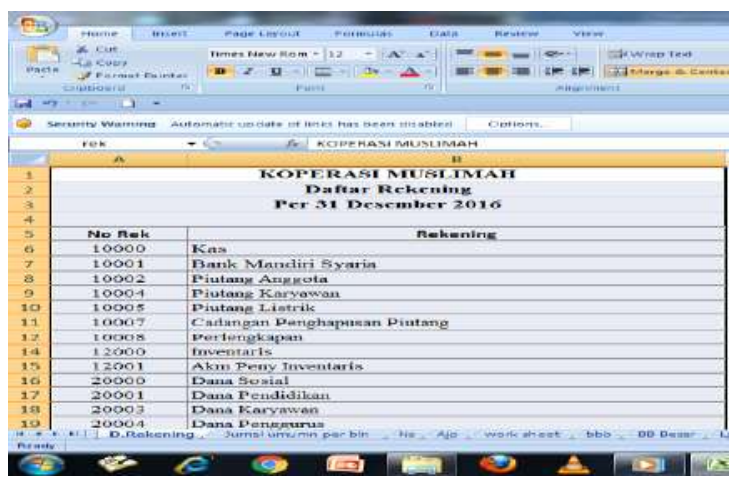

Daftar rekening lalu di sorot mulai dari cell A5 sampai dengan cell B20 atau keseluruhan dan lalu diberi nama range “ Rek "langka pembuatan range ini dapat dilakukan dengan mengetikkan langsung .Membuat range dapat juga 
dilakukan dengan Pilih

Formula,Define Name,lalu ketik Rek,Oke

\section{b. Jurnal Umum}

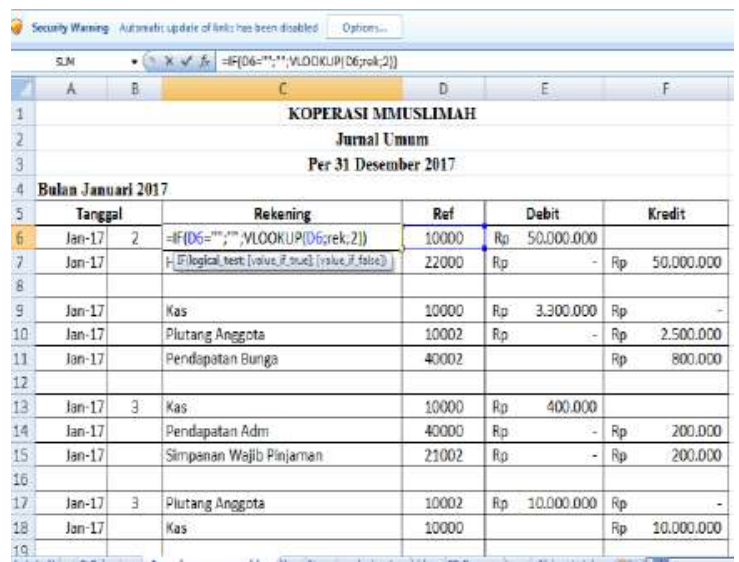

Pada Cell C6 atau kolom rekening masukkan

Rumus

IF(C6="";,"";VLOOKUP(C6;Rek;2)).Ru mus ini dicopy sampai Cell B45.pada Cell B50 Ketik Jumlah dan pada Cell D50 Isikan Rumus =Sum(D6;D45).Rumus ini copy untuk Cell E50. Langka pengisian jurnal adalah :

1. Isikan tanggal terjadinya transaksi sebnayak rekening yang terpengaruh,seperti transaksi tanggal 1 desember yang terpengaruh adalah Kas dan Modal berarti tanggalnya pada kolom tanggal diisi dua baris.

2. Isikan Nomor Rekening yang terpengaruh akibat dari satu transaksi .Seperti transaksi bulan Januari ketik pada cel D14 atau kolom Ref nomor rekening Piutang Anggota ( 10002) dan Nomor Rekening Kas (10000 ).Dengan mengisi ini Rekening akan muncul secara otomatis.
3. Isikan angka debet dan angka kredit sesuai dengan nilai transaksi masingmasing.

4. Apabila dalam soal ada data awal perusahaan,maka data awal itu dibuat jurnal umumnya seperti mencatat jurnal jurnal yang lain.

Lakukan langkah ini sampai semua transaksi selesai dianalisa dan dibuatkan jurnalnya.

Pada cell D6 sampai cell D45 Disorot lalu dibuatkan Nama Range “ NJU”.Cara menbuat range ini bisa diketik langsung atau dengan pilih Formula,Define Name,lalu Ketik NJU,Ok.Pada Cell E6 sampai dengan E45 Disorot lalu dibuatkan Nama Range “ DJU “ . Cara membuat range ini bisa diketik langsung atau dengan pilih Formula,Define Name,lalu Ketik DJU,Ok. Pada Cell F6 sampai dengan F45 Disorot lalu dibuatkan Nama Range " KJU “. Cara membuat range ini bisa diketik langsung atau dengan pilih Formula,Define Name,lalu Ketik KJU,Ok.

\section{c. Neraca Saldo}




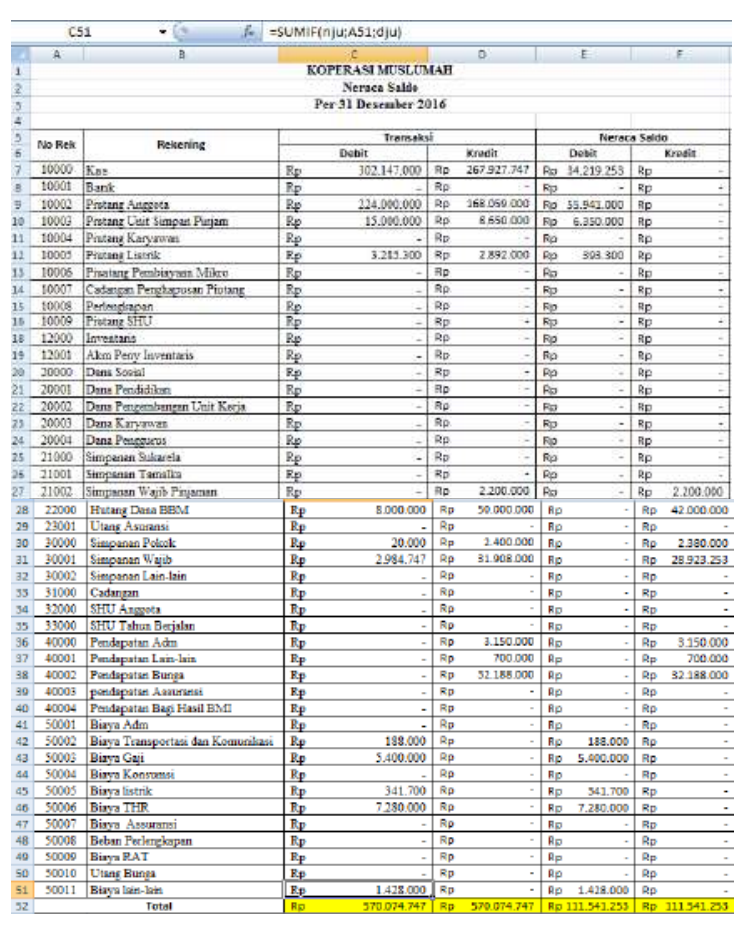

Langka pengisian Neraca Saldo adalah :

1. Copy No.Rekening dan Rekening dari daftar rekening yang telah dibuat sebelumnya.

2. Pada kolom Debet Transaksi atau C7 masukan rumus $=$ SUMIF(NJU;A7;DJU). Rumus ini dicopy sampai Cell C51.

3. Pada kolom Kredit Transaksi atau D7 masukan rumus =SUMIF(NJU;A7;KJU). Rumus ini dicopy sampai Cell D51.

4. Pada kolom Kredit Neraca Saldo atau E7 masukan rumus $=\mathbf{I F}(\mathbf{C} 7>\mathbf{D} 7 ; \mathbf{C} 7-$ D7;0). Rumus ini dicopy sampai Cell E51.

\section{d. Jurnal Penyesuaian}

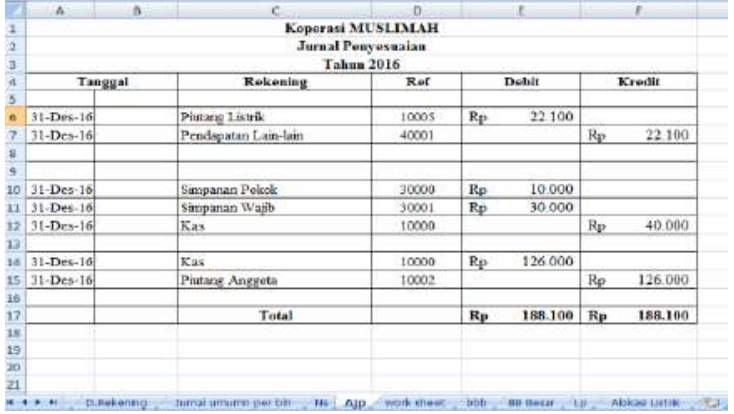

Pada Cell D6 atau kolom rekening Masukan rumus $=\mathrm{IF}(\mathrm{C6}$ ="";";";VLOOKUP(D6;Rek;2 )). Rumus ini di Copy sampai Cell C6,Pada Cell C22 Ketik Jumlah dan pada Cell E21 isikan rumus =SUM(E6:E21). Rumus ini dicopy untuk Cell F22.

Langkah pengisian Jurnal Penyesuaian adalah :

1. Isikan tanggal terjadinya transaksi sebanyak rekening yang terpengaruh akibat adanya penyesuaian.

2. Isikan nomor rekening yang terpengaruh akibat dari satu transaksi penyesuaian.

3. Isikan angka debet dan kredit sesuai dengan nilai transaksi masing-masing lakukan langkah ini sampai semua transaksi selesai dianalisa dan dibuatkan jurnalnya.

4. Pada Cell D6 sampai Cell D21 disorot lalu dibuatkan Nama Range “ NJP”. Cara Membuat range ini bisa diketik langsung atau pilih Formula,define Name,Lalu Ketik NJP,Ok.

5. Pada Cell E6 sampai Cell E21 disorot lalu dibuatkan Nama Range “ DJP”. Cara Membuat range ini bisa diketik langsung atau pilih Formula,define Name,Lalu Ketik DJP,Ok.

6. Pada Cell F6 sampai Cell F21 disorot lalu dibuatkan Nama Range “ KJP”. Cara Membuat range ini bisa diketik 
langsung atau pilih Formula,define

Name,Lalu Ketik KJP,Ok.

\section{e. Neraca Lajur}

Siapkan Neraca Lajur pada Work Sheet baru dengan nama Neraca Lajur. Dengan kolom No.rek,Rekening,Neraca Saldo ( Debet,Kredit ), Penyesuaian ( Debet,Kredit),Neraca Saldo disesuaikan ( Debet,Kredit ), Rugi Laba ( Debet,Kredit ), Neraca ( Debet,Kredit ). Seperti dibawah ini

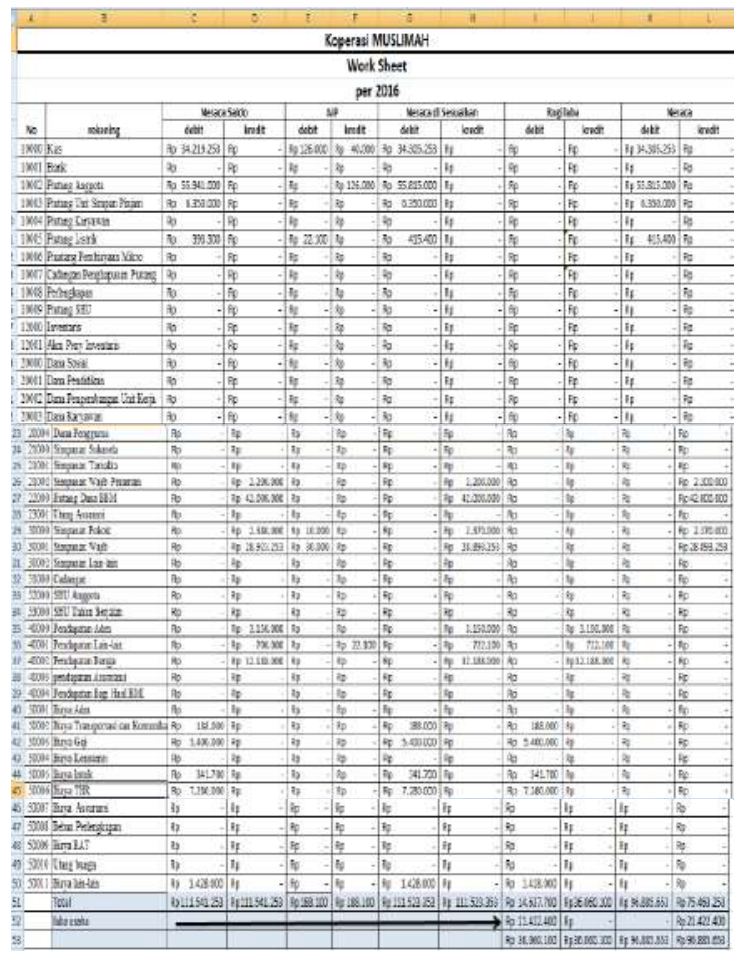

\section{Langka Pengisian Neraca Lajur adalah :}

1. Copy Nomor rekening dan rekening dari daftar rekening yang telah disediakan.

2. Pada kolom Debet Neraca saldo cell C6 isikan rumus (

3. =VLOOKUP(A6;NS;3), Lalu copy sampai cell C50.

4. Pada kolom Kredit Neraca saldo cell D6 isikan rumus ( =VLOOKUP(A6;NS;4),Lalu copy sampai cell D50.
5. Pada kolom Debet Penyesuaian saldo cell E6 isikan rumus ( $=$ SUMIF(NJP;A6;DJP),Lalu copy sampai cell E50.

6. Pada kolom Kredit Penyesuaian saldo cell F6 isikan rumus ( $=$ SUMIF(NJP;A6;KJP), Lalu copy sampai cell F50.

7. Pada kolom Debet Neraca saldo disesuaikan cell G6 isikan rumus $=\mathrm{IF}(\mathrm{C} 6+\mathrm{E} 6>\mathrm{D} 6+\mathrm{F} 6 ;(\mathrm{C} 6+\mathrm{E} 6)$ (D6+F6);0), Lalu copy sampai cell G50.

8. Pada kolom Kredit Neraca saldo disesuaikan cell H6 isikan rumus $=\mathrm{IF}(\mathrm{D} 6+\mathrm{F} 6>\mathrm{C} 6+\mathrm{E} 6 ;(\mathrm{D} 6+\mathrm{F} 6)$ (C6+E6);0), Lalu copy sampai cell H50.

9. Pada kolom Debet Rugi Laba cell I6 isikan rumus $=\mathrm{IF}(\mathrm{A} 6>4000 ; \mathrm{G6} ; 0$, Lalu copy sampai cell I50.

10. Pada kolom Kredit Rugi Laba cell J6 isikan rumus $=\mathrm{IF}(\mathrm{A} 6>4000 ; \mathrm{H} 6 ; 0$, Lalu copy sampai cell J50.

11. Pada kolom Debet Rugi Laba cell K6 isikan rumus $=\mathrm{IF}(\mathrm{A} 6<4000 ; \mathrm{G} 6 ; 0)$, Lalu copy sampai cell K50.

12. Pada kolom Kredit Rugi Laba cell L6 isikan rumus $=\mathrm{IF}(\mathrm{A} 6<4000 ; \mathrm{H} 6 ; 0)$, Lalu copy sampai cell L50.

Pada kolom jumlah untuk masingmasing kelompok mulai dari neraca saldo sampai ke neraca pakai rumus Sum sebagai berikut : $=\operatorname{SUM}(\mathrm{C} 6: \mathrm{C} 50)$ rumus ini dicopy sampai ke ujung cel neraca. Setelah langka ini selesai seluruh tabel neraca lajur mulai dari A6 sampai dengan L49 ditulis range dengan nama NL . Caranya dapat dengan mengetik langsung atau dengan langkah pilih Formula,Define Name,lalu Ketik NL,Ok. 


\section{f. Laporan Keuangan}

Laporan keuangan yang dimaksudkan disini adalah laporan rugi laba ( Income Statement), Laporan perubahan Modal ( Capital Statement ), dan Laporan Neraca ( Balance Sheet ). Sumber laporan ini adalah neraca lajur yang sebelumnya sudah kita selesaikan.

Langkah penyelesaiannya adalah ;

Buka lembaran Worksheet baru dan lalu beri nama dengan" Laporan "

\section{Laporan Laba rugi}

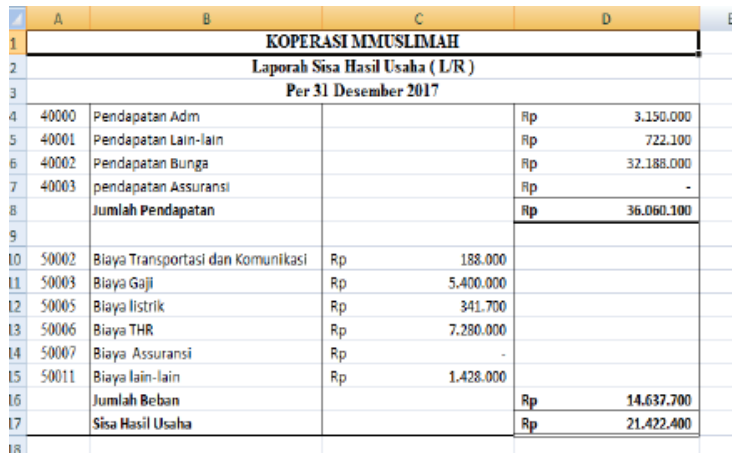

Pada Cell B4 Isikan Rumus $=$ VLOOKUP(A4;NL;2)) dan Copy Sampai Cell B15. Pada Cell D4 isikan rumus $=$ VLOOKUP(A4;NL;10)) Lalu copy sampai D15

Pada Cell $\mathrm{C} 4$ isikan rumus $=$ VLOOKUP(A4;NL;9)) dan lalu Copy sampai Cell C15. Pada Cell Jumlah Beban atau Cell D16 Isikan rumus $=\mathrm{SUM}(\mathrm{C} 10: \mathrm{C} 15)$ pada cell laba Usaha isikan rumus $=\mathrm{D} 8-\mathrm{D} 16$

1. Laporan Perubahan Laba
Ditahan

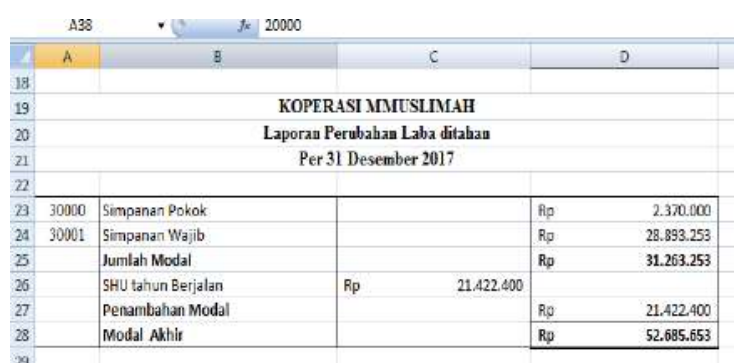

Pada Cell Simpanan pokok atau cell B23 Isikan rumus =VLOOKUP(A23;NL;2)) copy sampai A24 Pada Cell D23 isikan rumus $=$ VLOOKUP(A23;NL;12)) Pada Cell $\mathrm{C} 26$ atau laba usaha isikan rumus $=\mathrm{D} 17$ ( laporan laba rugi diatas ). Jika ada prive tinggal Tambahkan Cel dibawah dan masukan rumus seperti halnya simpanan pokok dan simpanan wajib.Pada cell penambahan Modal isikan rumus $=\mathrm{C} 26$ Jika Ada Prive masukan rumus $=\mathrm{C} 26-\mathrm{C} 27$. Pada Cell D28 atau modal akhir isikan rumus = D25+D27.

\section{Laporan Neraca}

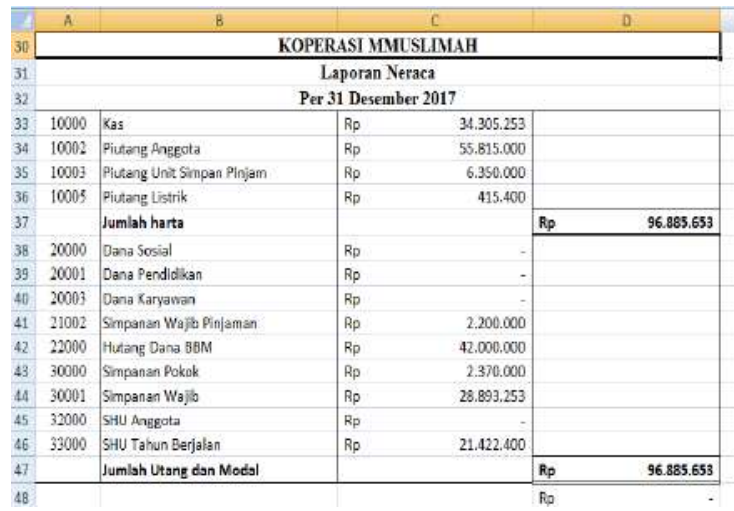

Pada Cell B33 Isikan rumus $=$ VLOOKUP(A33;NL;2)) dan lalu copy sampai Cell B36 . Pada Cell C33 isikan rumus =VLOOKUP(A33;NL;11)) dan lalu copy sampai Cell C36.dan pada bagian Akumulasi penyusutan masukan rumus =VLOOKUP(A33;NL;12)) Pada Cel 
C38 atau jumlah harta isikan rumus $=$ SUM $($ C33:C36). Pada Cell B38 Isikan rumus =VLOOKUP(A38;NL;2)) dan lalu copy sampai Cell C38 . Pada Cell C46 isikan rumus =VLOOKUP(A33;NL;12)) dan lalu copy sampai Cell C46. Pada Cell C47 isikan rumus $=\operatorname{SUM}(\mathrm{C} 38: \mathrm{C} 46)$.

\section{g. Merancang Buku Besar ( Ledger )}

1. Copy jurnal umum dan jurnal penyesuaian kedalam kertas kerja baru yang disebut dengan copy JU dan AJP.

2. Tambahkan Kolom keterangan Transaksi untuk menjelaskan masing,asing transaksi. Pada kolom keterangan diisi dengan keterangan ringkas yang menjelaskan tentang transaksi yang bersangkutan . seperti contoh transaksi tanggal 1 Januari diberi keterangan “ Pinjaman Modal Dari BMT ) hasil Lengkapnya adalah seperti dibawa ini :

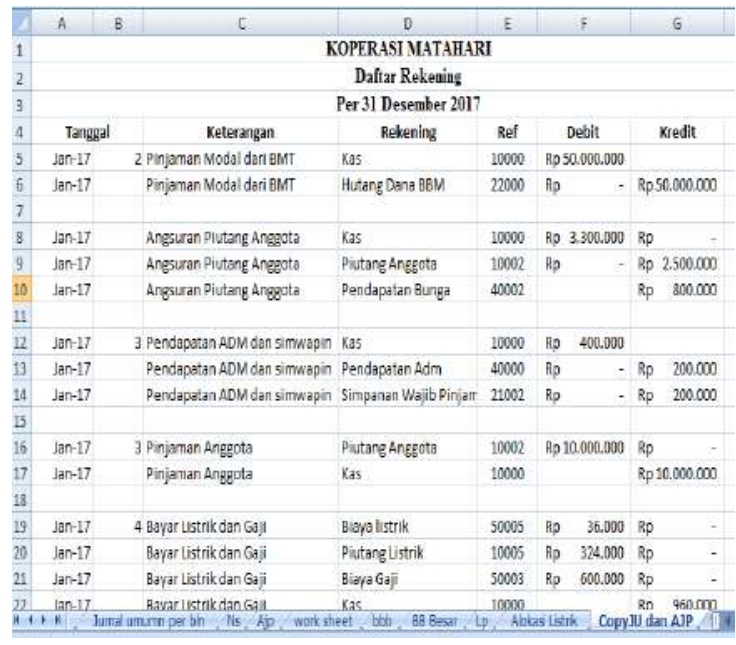

3. Sorot kertas kerja ini dari A5 sampai semua jurnal tersorot lalu tekas Data dan Filter seperti di bawah ini.

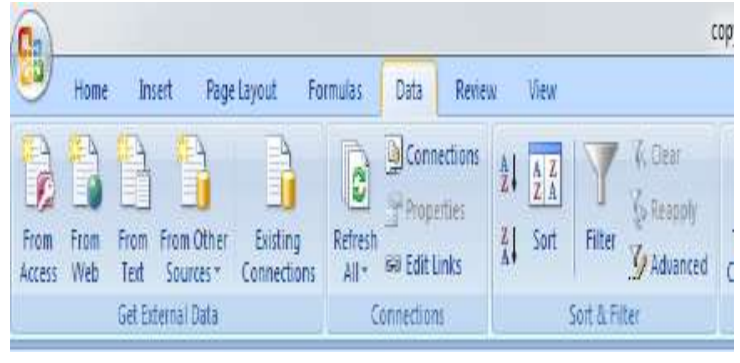

4. Setelah langkah ini kita lakukan,maka kita pilih

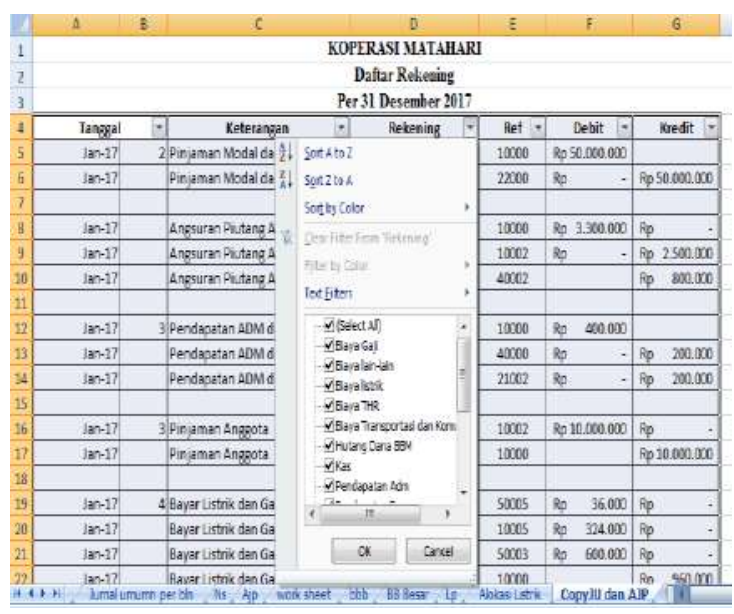

Filter melalui nomor rekening satu persatu,setelah itu dicopy kekertas kerja baru yang di sebut dengan BB ( Buku Besar ).Sebagai Contoh Kita Filter dengan memilih nomor rekening kas ( 10000 ),Maka Hasilnya adalah Sebagai berikut.

\begin{tabular}{|c|c|c|c|c|c|c|}
\hline 4 & A & c & 0 & E & 5 & G \\
\hline 1 & \multicolumn{6}{|c|}{ KOPERASIMAIAHARI } \\
\hline 2 & \multicolumn{6}{|c|}{ Baku Besar } \\
\hline 3 & \multicolumn{6}{|c|}{ Per 31 Desember 2017 ? } \\
\hline 4 & Tangegal & Keterangan & - Rekening & Ret 1 & Debit * & Kredit 1 \\
\hline 5 & $160 \cdot 17$ & 2 Pinfaman Nodal dari eanT & Kas & 10000 & 70,50.000.000 & \\
\hline 8 & Jar:-17] & Argssuran Piutarg Anggota & Kas & 10000 & fip 3.300 .000 & Rp \\
\hline 12 & $\operatorname{lon}: 17$ & 3 Pendaptan AOM don simwapin & in $k 35$ & 10000 & Fo 400.000 & \\
\hline 17. & 18n:17] & Pinjamen Anggote & $\mathrm{K} 25$ & 10000 & & Rp 105000.000 \\
\hline 22 & Jan:17 & Bayar Listikdan Gaji & Kas & 10000 & & Rp 9600.000 \\
\hline 24 & $\operatorname{Jan}: 17$ & 31 Renerimasn piutang Listrik & Kas & 10000 & Bp $\quad 324.000$ & \\
\hline 27 & Feb-17] & 4 Penenmaan Putang Anggota & $\mathrm{kas}$ & 10000 & Fp 55.000 & \\
\hline 31 & feb-17 & 6 simpanan Wojijto & Kas & 10000 & Bp, 2400.000 & \\
\hline 36 & Feb-17 & pinjamen anggots & Kas & 10000 & Bp & Rp 15.000.000 \\
\hline 38 & Feb-17] & penerimaan kas & Kas & 10000 & Ap 14.150 .000 & $\operatorname{Rp}$. \\
\hline 46 & feb-17 & Bayar Listik & Kas & 10000 & fip $\quad$. & Rp 250.000 \\
\hline 48 & feb-17 & penerimsan piutang listik. & Kas & 10000 & Ap 285.000 & \\
\hline 51. & Feb-17 & Peneriman kas & Kas & 10000 & Hp 2115.000 & $R_{p}$ \\
\hline 60 & Feb-17 & pengeluaran Kas & Kas & 10000 & & Rp 40.349.4.45 \\
\hline 64 & Feb-17 & byyar listik & Kas & 10000 & & Ap 380.000 \\
\hline 66 & Mar.17] & 6 Penerimsan piutang angsota & kas & 10000 & Ro 201.574.000 & \\
\hline$\pi$ & Mar.17] & 14 Penerinża kas & Kas & 10000 & Fp 5.252.000 & \\
\hline (n) & Mar-17 & 2engefuran kasseiutros dan bi & bialkas & $1 \mathrm{~nm}$ & & 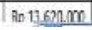 \\
\hline
\end{tabular}


Buku besar ini akan disesuaikan dengan kebutuhan dengan menambahkan kolom saldo. Dengan cara klik kanan lalu insert,pada kolom (H7) saldo dimasukkan rumus sebagai berikut ( = F7 ) dan pada kolom H8 isikan rumus $(=\mathrm{H} 7+\mathrm{F} 8-\mathrm{G} 8)$ jadinya adalah sebagai berikut :

\begin{tabular}{|c|c|c|c|c|c|c|}
\hline A & c & 0 & $E$ & $\mathrm{~F}$ & 6 & H \\
\hline \multicolumn{7}{|c|}{ KOPERASI WLATAHARI } \\
\hline \multicolumn{7}{|c|}{ Buku Besar } \\
\hline \multicolumn{7}{|c|}{ Pet 31 Desenker 2017? } \\
\hline Kas & & & & & Nadec 1000 & \\
\hline Tangegs! & Reterangan & Retening & Ret. & Debit & Kiedit & Saldo \\
\hline & Salto Anal & & & & & \\
\hline Jan-17 & 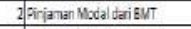 & ks & 10000 & Ap sa.000.0xo & & $=-77+78-a d$ \\
\hline Jan-17 & Angsuran Pi.tang Anssola & Kes & 10000 & \begin{tabular}{|l|l|} 
Ap & 3.3000000 \\
\end{tabular} & App & 53,300000 \\
\hline Jan-217 & 3 Pendepatan ADU dan Sinuragin & kes & 10000 & monoxo & & 53702000 \\
\hline Jen-17 & Pirijnan Angevols & kes & 10000 & & 10000.000 & 43,7000000 \\
\hline $\operatorname{lan}-17$ & Bajar Ustrikik dan Gaji & kas & 10000 & & $900: 000$ & 427400000 \\
\hline Jan-27 & 31. Anenerinazan pivarag Listitix & Kes & 10000 & $324 \times 00$ & & 83.0540000 \\
\hline Fet-17 & 4. Aenerinaz Piutarg Angesto & kas & 10000 & 57.000 & & 43.639000 \\
\hline Fet-17 & Elsimparan Wǟo & kas & 10000 & 20000000 & & 460390000 \\
\hline Fet-17 & 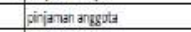 & Kes & 10000 & Ap & $\begin{array}{|ll|}\text { Rp } & 15000.000 \\
\end{array}$ & 310390000 \\
\hline Fet-17 & Fenerimas las & Kes & 10000 & $\begin{array}{|ll|}\text { Ap } & 14.150 .000 \\
\end{array}$ & Ap & 45,139000 \\
\hline $\mathrm{Fet}-17$ & Begar Listīix & kes & 10000 & Ap & 250,000 & 44939000 \\
\hline Fet-17] & 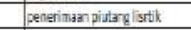 & kes & 10000 & 250000 & & 45.1510000 \\
\hline Fet-17 & Penerimazi las & kas & 10000 & 2.1350 .00 & $R_{p}$ & 47.2990000 \\
\hline Feb-17 & sengelbatan Kas & Cas & 10000 & & $\begin{array}{|ll|}\text { Aq7 } & 403193.103 \\
\end{array}$ & 6999597 \\
\hline 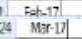 & 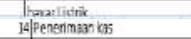 & $\begin{array}{l}2 \times 6 \\
k 15\end{array}$ & $\begin{array}{l}19 \mathrm{~mm} \\
10000\end{array}$ & 502000 & $8 \pi$ & $\begin{array}{l}5 \mathrm{SSA} 597 \\
36.455 .597\end{array}$ \\
\hline $\begin{array}{lll}25 & \mathrm{Mr} \cdot \mathrm{Cl} \\
\end{array}$ & 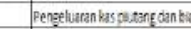 & & 10000 & & Ro 13.50.000 & 2855.597 \\
\hline \begin{tabular}{ll|l|}
28 & Mr. 17 \\
\end{tabular} & Eeqrilstsis & $\mathrm{kis}$ & 10000 & & 450.000 & 20.46 .597 \\
\hline 27 $\quad$ Mrer.17 & Pengeluruan kass & k.5 & 10000 & & 4.300 .34 & 18.117 .253 \\
\hline 25 4scr-17 & Penerimank ks & 635 & 10000 & Rp $\quad 27.8580 x$ & & 46.75 .231 \\
\hline 28 acr-17 & Peneriman kes & ks & 10000 & Rs $\quad 20000$ & & 46.275 .291 \\
\hline 32 Ascr-17 & Pengefuran kas & Las & 10000 & & 10.00 .000 & 36.25 .259 \\
\hline 31 Acr.17 & Pengzefuren kas & k.5 & 10000 & & 370.000 & 35.85 .259 \\
\hline $32 \quad 4 \mathrm{sc}-27$ & peneriman ces & Kas & 10000 & 344000 & & 3.179 .26 \\
\hline 33 Mei-17 & penzeluaran Kass: & Kas & 10000 & & 1.606 .000 & 35.110 .253 \\
\hline $\begin{array}{ll}34 \\
34 n-127 \\
\end{array}$ & pensinas kas & K.5.5 & 10000 & $\begin{array}{|ll|}\text { R. } & 19339.000 \\
\end{array}$ & & $54,452.253$ \\
\hline 35 Jur-17 & pengeluaran Kas & 8.5 & 10000 & & 17250.002 & 37.203 .253 \\
\hline$3 6 \longdiv { \mathrm { Ju } - 1 2 7 }$ & peneitiman kas & Kas & 10000 & $\begin{array}{|ll|}\text { Ro } & 383580000 \\
\end{array}$ & & 75.57 .1253 \\
\hline 37 $\quad$ Ju:17 & pengeluatan Kas & $\mathrm{k}$. & 10000 & & 29:84:000 & 45.57 .253 \\
\hline 38 Agst:17 & penctinan ka & kis & 10000 & Ro 269320000 & & 70.599 .253 \\
\hline 39 hasst:17 & pengegluaran Kas. & $k \cdot x_{5}$ & 10000 & & 40.97:000 & $29,588.253$ \\
\hline 90 $\mathrm{sep} \cdot 17$ & penerinar kas & Ris & 10002 & R., 22.702500 & & 57.340 .253 \\
\hline $41 \quad$ sep-17 & pengeturankes & $\mathrm{k}, 5$ & 10000 & & $\begin{array}{ll}\text { R.9 } & 25.999 .000 \\
\end{array}$ & 31.550 .250 \\
\hline 42 ant 17 & penenmaen kes & k.5 & 10000 & Rp 40.999000 & & 72.299 .253 \\
\hline 4e 0 ant-17 & Pengelueran ras & kns & 10000 & & Ro 57.000 .002 & 15280.203 \\
\hline 44 Nop-16 & Peneriman kes & $\pi 5$ & 10000 & Ro 18930000 & & 34.219 .253 \\
\hline
\end{tabular}

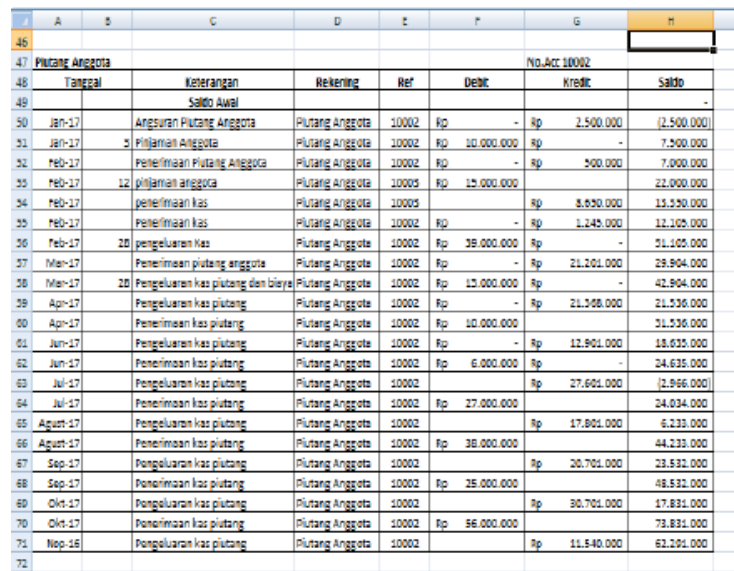

\section{DAFTAR PUSTAKA}

http://www.bengkuluonline.com/2014/04/20 14-koperasi-di-kota-bengkulu-capai788-unit.html (diakses April 20, 2014)

Ikatan Akuntan Indonesia (2009), Standar Akuntansi Keuangan Entitas Tanpa Akuntabilitas Publik, Jakarta: Dewan Standar Akuntansi Keuangan. (online) (http://sutaryofe.staff.uns.ac.id/files /2011/06/sak-etap.pdf).

Iim Ma'rifatul Auliyah (2008) Penerapan Akuntansi Berdasrkam SAK ETAP pada UKM Kampung Batik di Sidoarjo : Artikel Ilmiah (online) (http://katalog.library.perbanas.ac.i d/download 6313 artikel.pdf).

Mackenzie Bruce dkk, (2012). IFRS for SMEs. Jakarta: Indeks.

Ngada Orang (2012). Lampiran Permen KUKM Republik Indonesia No. 04 Tentang Pedoman Umum Akuntansi Koperasi. (Online) (http://ngada.org/bn7552012lmp.htm). 